\title{
Cattle Diets in the Blue Mountains of Oregon II. Forests
}

\section{Abstract}

Esophageally fistulated cows were used on forested range in northeastern Oregon to collect diet samples which were then analyzed by the microhistological technique. Grasses, forbs, and shrubs averaged 61,16 , and $23 \%$ of the diet, respectively. Composition of diets differed among years and with seasonal advance. Idaho fescue and elk sedge were the most important forage species consumed. Forbs were used heavily in the early part of the grazing season before maturation. Browse comprised as much as $\mathbf{4 7 \%}$ of the diet when green grass was unavailable. Cattle were opportunistic grazers and did not limit their selection to grass species. On forested ranges cattle diets varied among grazing periods within each year as well as among years.

Knowledge of dietary habits of livestock and game animals is valuable to the range manager in determining if competition exists among different range animals and in balancing livestock and game numbers with available forage. Also, a knowledge of species consumed tells a manager what the key species are and helps explain changes in diet quality and animal performance (Holechek et al. 1981). At present information concerning cattle diets on forested range in eastern Oregon is limited to utilization studies reported by Pickford and Reid (1948), Harris (1954), Miller and Krueger (1976), and Skovlin et al. (1976).

Pickford and Harris (1948), Harris (1954), and Skovlin et al. (1976) conducted their research at the Starkey Experimental Range and Forest in northeastern Oregon. Results from all three studies showed that bluebunch wheatgrass (Agropyron spicatum), Idaho fescue (Festuca idahoensis), prairie junegrass (Koeleria cristata), elk sedge (Carex geyeri), Sandberg bluegrass (Poa sandbergii), and pinegrass (Calamagrostis rubescens) were the primary forage species considering availability and utilization.

Pickford and Reid (1948) reported that grass was the primary forage class consumed by cattle but forbs were readily utilized in June and early July. Shrubs, particularly common snowberry (Symphoricarpos albus), also received heavy use during some periods although shrubs comprised a small amount of the available forage. Harris (1954) observed that over a 9-year period bluebunch wheatgrass was the forage species most heavily used by cattle followed by prairie junegrass, Idaho fescue, elk sedge, and pinegrass. Skovlin et al. (1976) also found that bluebunch wheatgrass was an important forage species. Elk sedge and pinegrass, however, contributed the most forage. In all three of the previously discussed investigations, Sandberg bluegrass (Poa sandbergii) was one of the most common forage species present but utilization

\footnotetext{
Authors were, respectively, graduate research assistant; associate professor rangeland resources, Oregon State University, Eastern Oregon Agricultural Research Center, Union, Oregon; professor, project leader, U.S. Dep. Agr. Range and Wildlife Habitat Laboratory, La Grande, Oregon; and leader, rangeland resources program. Oregon State University, Corvallis, at the time of the research. J.L. Holechek is currently assistant professor of range science, Division of Animal and Range Sciences, New Mexico State University, Las Cruces, New Mexico 88003.

This report is Oregon State Agricultural Experiment Station Technical Paper Number 5400 . This research was jointly funded by the Eastern Oregon Agricultural Research Center, Oregon State University and the Pacific Northwest Forest and Range Experiment Station, United States Forest Service, U.S. Dep. Agr., and was part of the PNWFRES Project 1701 entitled, "The influence of cattle grazing methods and big game on riparian vegetation, aquatic habitat and fish populations."
}

levels were much below those for bluebunch wheatgrass, prairie junegrass, Idaho fescue, and elk sedge.

Pickford and Reid (1948) observed cattle during the grazing season and reported a preference for grasslands. Forest areas were generally utilized by mid-summer. However, Harris (1954) stated that cattle used forest areas all summer when heat and/or flies became intense, although a preference for grassland areas were shown. In these studies cattle grazed an 8500-ha range area divided into two pastures and grazed under deferred rotation.

The objectives of this study were to restrict cattle to forest ranges and determine important dietary constituents, estimate changes in diet with season progression and to observe annual differences in dietary constituents.

\section{Experimental Site and Procedure}

The study was conducted on a portion of the Starkey Range described by Holechek et al. (1981). In 1976, two 230-ha pastures were established on a range having a common grazing history. The vegetation and terrain of the two pastures was similar. Vegetation is representative of the ponderosa pine-Idaho fescue (Pinus ponderosa-Festuca idahoensis), ponderosa pine-common snowberry-elk sedge (Pinus ponderosa-Symphoricarpos albusCarex geyeri), Douglas fir-ninebark (Pseudotsuga menziesiiPhysocarpus malvaceus), and Douglas fir-common snowberry-elk sedge (Pseudotsuga menziesii-Symphoricarpos albus-Carex geyeri) associations originally described by Daubenmire and Daubenmire (1968). Percent cover of important forage species on the pasture was determined and presented in Table 1. Because the vegetation composition on the two pastures was identical, cover data were pooled across pastures. Scientific and common names in Table 1 and the text follow Garrison and Skovlin (1976).

Cattle grazing was conducted on the pastures in 1976, 1977, and 1978 under a two pasture-one herd rest rotation grazing system. This involved grazing one pasture all season long in 1976 and resting the other pasture. In 1977 grazing was initiated on the pasture rested in 1976. At mid-season cattle were moved to the other pasture. In 1978, the pasture rested in 1976 was grazed while the other pasture was rested the entire season. Grazing was initiated on June 20 and concluded on October 10 in all three years of study.

Diet samples were collected with four esophageally fistulated cows in all three years of study. Eighteen head of yearling heifers and four fecal collector steers were also grazed on the pastures. Data on diet quality, forage intake, and livestock performance are given in Holechek et al. (1981). Two collections were made every other week with thet fistulated animals. The grazing season was divided into four 28-day periods to show trends in dietary botanical composition. These were June 20 to July 18 (late spring), July 19 to August 15 (early summer), August 16 to September 12 (late summer), and September 13 to October 10 (fall). Sixteen esophageal fistula samples were collected during each period.

Diet samples were analyzed for botanical composition by the Sparks and Malechek (1968) method. Where applicable, regres- 
Table 1. Percent cover of the primary forage species and their percent by weight contribution to cattle diets.

\begin{tabular}{lcc}
\hline \hline Species & $\begin{array}{c}\text { Percent } \\
\text { cover }^{1}\end{array}$ & $\begin{array}{c}\text { Percent } \\
\text { in diet }^{2}\end{array}$ \\
\hline Bluebunch wheatgrass (Agropyron spicatum) & 3 & 5 \\
Elk sedge (Carex geyeri) & 6 & 12 \\
Pinegrass (Calamogrostis rubescens) & 3 & 4 \\
One-spike danthonia (Danthonia & & \\
$\quad$ unispicata) & 3 & 1 \\
Idaho fescue (Festuca idahoensis) & 17 & 23 \\
Western fescue (Festuca occidentalis) & 3 & 6 \\
Kentucky bluegrass (Poa pratensis) & 2 & 4 \\
Sandberg bluegrass (Poa sandbergii) & 3 & 1 \\
$\quad$ Total grasses & 47 & 61 \\
Western yarrow (Achillea millefolium & & \\
$\quad$ lanulosa) & 2 & 2 \\
Heartleaf arnica (Arnica cordifolia) & 2 & 4 \\
Wyeth eriogonum (Eriogonum heracleoides) & 2 & T \\
Lupinc (Lupinus spp.) & 3 & 1 \\
Cluster tarweed (Madia glomerata) & 3 & - \\
$\quad$ Total forbs & 28 & 16 \\
Bearberry (Arctostaphylos uva-ursi) & 1 & $\mathrm{~T}$ \\
Ninebark (Physocarpus malvaceus) & 8 & 5 \\
Wax currant (Ribes cereum) & 1 & 1 \\
Spiraea (Spiraea betulifolia lucida) & 2 & 5 \\
Common snowbcrry (Symphoricarpos & & \\
albus) & 10 & 11 \\
Total shrubs & 25 & 23 \\
\hline Cover data (Ganskopp I978) were & & \\
\hline
\end{tabular}

'Cover data (Ganskopp 1978) were pooled across pastures.

2Diet samples were pooled across years and periods.

$T=$ Trace

sion equations (Vavra and Holechek 1980) were applied to correct for sample preparation breakdown of epidermal material.

Differences in consumption of individual species among periods within each of three years of study were determined by analysis of variance using a completely randomized design (Steel and Torrie 1960). Duncan's new multiple range test was used to rank the consumption of each species among periods. Similarity indices (Oosting 1956) as applied to dietary analysis (Olsen and Hansen 1977) were used to observe variation in diets among grazing periods within each year and between years.

\section{Results and Discussion}

Idaho fescue, elk sedge, and common snowberry constitute almost half of the diet when samples were pooled across period and years (Table 1). The most important species found in die samples in the three years of study was Idaho fescue, which wa also the most common species based on cover on the pastures. Th consumption of both Idaho fescue and snowberry was relative $t_{1}$ a vailability. However, elk sedge appeared to be a preferred specie based on consumption and cover.

A total of 29 graminoids were identified in diet samples but onl six occurred in greater than trace amounts. Important graminoid other than Idaho fescue and elk sedge included bluebunch wheat grass, pinegrass, western fescue, and Kentucky bluegrass. Each o these contributed $5 \%$ or more to the overall diet and were heavil: utilized during given sampling periods.

Thirty-one forb species were found in cattle diets but only west ern ya rrow, heartleaf arnica, and lupine comprised $1 \%$ or more o the overall diet. Several species were important in particular collec tions or for short periods of time during the early part of th grazing season. Forb consumption by cattle was limited by shor periods of forb palatability and/or limited production or distribu tion on the pastures.

Important shrubs found in diet samples in addition to snowberry included spiraea, ninebark, and wax currant. Five other shrub: were consumed in trace amounts.

Several researchers have reported that cattle graze primarily grass (Cook et al. 1963, Van Dyne and Heady 1965, Cook et al 1967, Beck 1975), but in this study quantities of grass consumec depended upon period and the palatability of all forage available Grass content of diets varied from as low as $36 \%$ in late spring $197 \%$ to as high as $83 \%$ in late summer 1977 .

During the late spring most graminoids found on the pastures were consumed; but in the latter half of the grazing season, Idahc fescue and elk sedge comprised $59 \%$ of the graminoid portion of the diet when data were pooled across years. These two species were less advanced in phenological development than other graminoids and forbs. Pickford and Reid (1948) reported elk sedge was highly preferred in the late summer and fall because it remained green and succulent after other graminoids had matured.

Forb consumption declined as the grazing season advanced in al three years of study. Most forbs were green and succulent whe cattle grazing was initiated but had matured by the end of earl summer. Pickford and Reid (1948) reported a downward trend is

Table 2. The percent by weight of important species found in cattle diets in 1976, 1977, and 1978.

\begin{tabular}{|c|c|c|c|c|c|c|c|c|c|c|c|c|}
\hline & \multicolumn{4}{|c|}{1976} & \multicolumn{4}{|c|}{1977} & \multicolumn{4}{|c|}{1978} \\
\hline & $\begin{array}{l}\text { Late } \\
\text { spring }\end{array}$ & $\begin{array}{l}\text { Early } \\
\text { sum- } \\
\text { mer }\end{array}$ & $\begin{array}{l}\text { Late } \\
\text { sum- } \\
\text { mer }\end{array}$ & Fall & $\begin{array}{l}\text { Late } \\
\text { spring }\end{array}$ & $\begin{array}{l}\text { Early } \\
\text { sum- } \\
\text { mer }\end{array}$ & $\begin{array}{l}\text { Late } \\
\text { sum- } \\
\text { mer }\end{array}$ & Fall & $\begin{array}{l}\text { Late } \\
\text { spring }\end{array}$ & $\begin{array}{l}\text { Early } \\
\text { sum- } \\
\text { mer }\end{array}$ & $\begin{array}{l}\text { Late } \\
\text { sum- } \\
\text { mer }\end{array}$ & Fall \\
\hline Bluebunch wheatgrass & $3^{b}$ & $14^{b}$ & $13^{\mathrm{a}}$ & 6 & 2 & 2 & 5 & 2 & 1 & 4 & 2 & $\mathrm{~T}$ \\
\hline Elk sedge & $9^{b}$ & $10^{b}$ & $4^{c}$ & $17^{a}$ & $2^{b}$ & $7^{b}$ & $23^{a}$ & $24^{\mathrm{a}}$ & $5^{b}$ & $8^{b}$ & $8^{b}$ & $22^{a}$ \\
\hline Pinegrass & 2 & $\mathrm{~T}$ & 2 & 1 & $2^{b}$ & $6^{n}$ & $2^{b}$ & $3^{b}$ & 2 & 2 & $\mathrm{~T}$ & 5 \\
\hline Idaho fescue & $9^{c}$ & $28^{\mathrm{a}}$ & $29^{\mathrm{a}}$ & $20^{b}$ & $18^{b}$ & $28^{\mathrm{a}}$ & $29^{a}$ & $29^{a}$ & $31^{\mathrm{a}}$ & $22^{b}$ & $17^{b c}$ & $13^{c}$ \\
\hline Western fescue & 4 & 4 & 4 & 3 & 2 & 3 & 1 & $\mathbf{T}$ & 3 & 3 & 3 & 3 \\
\hline Kentucky bluegrass & 4 & 6 & 4 & 1 & 3 & 3 & 5 & 4 & $4^{b}$ & $\mathbf{T}$ & $2^{b}$ & $8^{a}$ \\
\hline Total grasses & $49^{b}$ & $73^{a}$ & $76^{\mathrm{a}}$ & $58^{b}$ & $36^{\mathrm{c}}$ & $57^{b}$ & $83^{a}$ & $76^{\mathrm{a}}$ & $52^{b}$ & $67^{\mathrm{a}}$ & $3 T^{c}$ & $74^{\mathrm{c}}$ \\
\hline Western yarrow & 3 & 1 & 3 & 1 & $T$ & 2 & 2 & 2 & 1 & 1 & 2 & 2 \\
\hline Heartleaf arnica & $14^{\mathrm{a}}$ & $6^{b}$ & $3^{b}$ & $\mathrm{~T}$ & 5 & 1 & $\mathbf{T}$ & $T$ & 4 & 2 & 2 & 2 \\
\hline Lupine & 3 & $\mathrm{~T}$ & - & & 4 & $\mathbf{T}$ & - & $\mathbf{T}$ & 3 & 1 & 1 & - \\
\hline Total forbs & $36^{\mathrm{a}}$ & $14^{b}$ & $11^{b}$ & $12^{b}$ & $26^{\mathrm{a}}$ & $13^{b}$ & $\tau^{c}$ & $6^{c}$ & $25^{\mathrm{a}}$ & $12^{b}$ & $16^{b}$ & $10^{b}$ \\
\hline Ninebark & - & - & - & 3 & $5^{b}$ & $12^{\mathrm{a}}$ & $\mathbf{T}$ & $8^{a}$ & $7^{b}$ & $6^{b}$ & $12^{\mathrm{a}}$ & $3^{b}$ \\
\hline Wax current & $\mathbf{T}$ & $\mathbf{T}$ & - & - & & & & & 2 & 1 & 6 & 3 \\
\hline Spiraea & 5 & 3 & 1 & 5 & $8^{a}$ & $4 b$ & $T$ & $1^{\mathbf{b}}$ & $3^{b}$ & $5^{b}$ & $18^{a}$ & $3^{b}$ \\
\hline Common snowberry & $9^{b}$ & $8^{b}$ & $9^{b}$ & $20^{\mathrm{a}}$ & $24^{a}$ & $13^{b}$ & $9^{b c}$ & $T^{\mathbf{c}}$ & 8 & 8 & 9 & 6 \\
\hline Total shrubs & $15^{b}$ & $13^{b}$ & $13^{b}$ & $30^{\mathrm{a}}$ & $38^{b}$ & $30^{c}$ & $10^{b}$ & $18^{c}$ & $23^{b}$ & $2 \mathrm{I}^{\mathrm{b}}$ & $47^{a}$ & $16^{b}$ \\
\hline
\end{tabular}

$\mathbf{a , b , c}$ Means with different superscripts within the same row and year are significantly different at the .05 level. 
forb consumption by cattle because of advanced phenological development.

A large number of unknown forbs were present in cattle diets. Because more than 200 forbs are found on the Starkey Range, identification of all forbs species in the diet would be difficult. Another problem encountered was that certain forb epidermal fragments were similar. An attempt was made to identify those species comprising more than $2 \%$ of the diet during a given period. Western yarrow and heartleaf arnica were utilized throughout the grazing season during the three years of study. Both species remained green and succulent until October in most years.

Shrub consumption was erratic among years and periods and depended on the availability of green grass and forbs. Other researchers have reported cattle increased shrub consumption when green grass was unavailable (Cook and Harris 1968, Lesperance et al. 1970, Rosiere et al. 1975). Many forbs and grasses were mature when grazing was initiated in 1977 because of a very dry winter and spring. Cattle grazed certain shrubs, particularly common snowberry, probably because the leaves were still green and succulent. Heavy rainfall occurred during summer (Table 1, Holechek et al. 1982) and grass regrowth became available in forest openings in fall causing a reduction in shrub consumption during the latter part of the grazing season. Late summer of 1978 was dry and little green grass was available compared to other periods. Browse comprised $47 \%$ of diets in this period. By fall, however, most of the green leaves on browse had dried and cattle switched back to grass.

Pickford and Reid (1948) also reported that shrubs received use during certain periods at Starkey; but only amounted to $8 \%$ of the total forage removed per acre. Harris (1954) and Skovlin et al. (1976) did not measure shrub and forb utilization by cattle.

In 1977 cattle were moved at mid-season and diets changed after movement. Because heavy rainfall occurred after movement no conclusions can be reached concerning the effect of movement on forage selection.

When diet similarities were compared between specific grazing periods within each study year little consistency was observed (Table 3). Diets on grasslands (Holechek et al. 1982) exhibited

Table 3. The percent similarity of cattle diets comparing grazing periods within years.

\begin{tabular}{lccc}
\hline & & Year & \\
\cline { 2 - 4 } Period comparison & 1976 & 1977 & 1978 \\
\hline LS - ESul & 47 & 52 & 55 \\
LS - LSu & 42 & 37 & 52 \\
LS - F & 41 & 40 & 44 \\
ESu - LSu & 66 & 54 & 54 \\
ESu - F & 52 & 61 & 42 \\
LSu - F & 46 & 67 & 45 \\
\hline
\end{tabular}

'LS = late spring, $E S u=$ early summer, $L S u=$ late summer, $F=$ fall.

lower similarity values when the late spring period was compared to the others than when early and late summer and fall periods were compared. Annual variation in similarity indexes was also greater on the forest (Table 4) than on the grassland (Holechek et al. 1982). The increased variability noted on the forest compared to the grassland was due to the increased diversity in plant communities present, and therefore a larger variety of plant species was available for diet selection. Maturation and drying of forbs on the grassland induced cattle into grazing more grass later in the season. On the forest in the latter half of the grazing season, however, cattle responsed to weather conditions by shifting their diets away from grasses to browse when green regrowth due to summer precipitation was not available. This difference in response on the forest compared to the grassland was because considerable browse was a vailable on the forest but relatively little browse was available on the grassland (Table 2, Holechek et al. 1982) and Table 1). able 4. The percent similarity of cattle diets comparing years within each grazing period.

\begin{tabular}{lcccc}
\hline \hline $\begin{array}{l}\text { Year } \\
\text { comparison }\end{array}$ & $\begin{array}{c}\text { Late } \\
\text { spring }\end{array}$ & $\begin{array}{c}\text { Early } \\
\text { summer }\end{array}$ & $\begin{array}{c}\text { Late } \\
\text { summer }\end{array}$ & Fall \\
\hline $1976-1977$ & 42 & 56 & 56 & 53 \\
$1976-1978$ & 43 & 51 & 42 & 48 \\
$1977-1978$ & 51 & 53 & 41 & 54 \\
\hline
\end{tabular}

\section{Conclusions}

Idaho fescue and elk sedge were the two most important species consumed by cattle grazing forested range in northeastern Oregon. Rocky Mountain elk and mule deer also make considerable use of Idaho fescue in winter (Skovlin and Vavra 1979) and elk use bluebunch wheatgrass in spring and early summer (Korfhage 1974). These graminoids should be regarded as key species for this range type, and management principles such as intensity of grazing should be based on their maintenance. Forbs and shrubs were also critical components of cattle diets and should be considered especially when forage allocations are being formulated for both livestock and wildlife. Pooled data indicated cattle made up 23\% of their diet of shrubs, much more than is generally recognized. Korfhage (1974) indicated forbs and shrubs were important summer dietary constituents of elk. These data indicate a need for continued research on food habits and distribution of cattle, mule deer, and elk to carry out the multiple use concepts mandated on public lands and insure proper management of the forage resource.

Low diet similarity indexes recorded indicate that cattle readily shift their diets during the grazing season and also from one year to the next during the same season. On forested ranges cattle are opportunistic grazers and may consume diets that frequently vary from the more common predominantly grass diet. A knowledge of dietary shifts in response to seasonal advance and precipitation induced forage regrowth should help managers optimize use of specific range types for improved grazing management and livestock production.

\section{Literature Cited}

Beck, Reldon. 1975. Steer diets in southeastern Colorado J. Range Manage. 28:48-52.

Cook, G.W., J.T. Blake, and J.W. Call. 1963. Use of esophageal fistula cannulae for collecting forage samples from both sheep and cattle grazing in common. J. Anim. Sci. 22:579-581.

Cook, C.W., L.E. Harris, and C.M. Young. 1967. Botanical and nutritive contcnt of diets of cattle and sheep under single and common use on mountain range. J. Anim. Sci. 26:1169-1174.

Cook, C.W., and L.E. Harris. 1968. Nutritive value of seasonal ranges. Utah Agr. Exp. Sta. Bull. 472.58 p.

Daubenmire, R., and J.B. Daubenmire. 1968. Forest vegetation of eastern Washington and northern Idaho. Washington Agr. Exp. Sta., Pullman. Tech. Bull. 60. 104 p.

Ganskopp, David Conrad. 1978. Plant communities and habitat types of the Meadow Creek Experimental Watershed. M.S. Thesis. Oregon State Univ., Corvallis. 152 p.

Garrison, G.A., and J.M. Skovlin. 1976. Plant names and symbols for ecosystem inventory analysis. Pacific NW Forest and Range Exp. Sta. PNW-46. 263 p.

Harris, R.W. 1954. Fluctuations in forage utilization on ponderosa pine ranges in eastern Oregon. J. Range Manage. 7:250-255.

Holechek, J.L., M. Vavra, J.M. Skovlin, and R.L. Phillips. 1981. Diet quality, and performance of cattle on grassland and forest range. J. Anim. Sci. 53:291-298.

Holechek, J.L., M. Vavra, J.M. Skovlin, and W.C. Krueger. 1980b. Cattle diets in the Blue Mountains of Oregon. I. Grasslands. J. Range Manage.

Korfhage, R.C. 1974. Summer food habits of elk in the Blue Mountains of northeastern Oregon based on fecal analysis. M.S. Thesis. Washington State Univ. Pullman. $117 \mathrm{p}$.

Lesperance, A.L., P.T. Tueller and V.R. Bohman. 1970. Symposium on pasture methods for maximum production in beef cattle; competitive use of the range forage resource. J. Anim. Sci. 30:115-120. 
Miller, Richard F., and William C. Krueger. 1976. Cattle use on summer foothill rangelands in northeastern Oregon. J. Range Manage. 29:367371 .

Olsen, Frank W., and Richard M. Hansen. 1977. Food relations of wild free-roaming horses to livestock and big game, Red Desert, Wyoming. J. Range Manage, 30:17-20.

Oosting, H.J. 1956. The study of plant communities. W.H. Freeman and Company, San Francisco. 440 p.

Pickford, G.D., and E.H. Reid. 1948. Forage utilization on summer cattle ranges in eastem Oregon. U.S. Dep. Agr. Circ. 796. 27 p.

Rosiere, R.E., J.D. Wallace, and R.F. Beck. 1975. Cattle diets on semidesert grassland: Botanical composition. J. Range Manage. 28:89-94.
Skovlin, J.M., R.W. Harris, G.S. Strickler, and G.A. Garrison. 1976. Effects of cattle grazing methods on ponderosa pine-bunchgrass range in the Pacific Northwest. U.S. Dep. Agr. Tech. Bull. No. 1531.40 p.

Skovlin, Jon, and Martin Vavra. 1979. Winter diets of elk and deer in the Blue Mountains of Oregon. U.S. Dep. Agr. Forest Serv. PNW Forest and Range Exp. Sta. Res. Pap. PNW-260. 21 p.

Sparks, D.R., and J.C. Malechek. 1968. Estimating percentage dry weight in diets using a microscopic technique. J. Range Manage. 21:264-265.

Steel, R.G., and J.H. Torrie. 1960. Principles and procedures of statistics. McGraw-Hill Book Co., Inc. New York. 481 p.

Van Dyne, G.M., and H.F. Heady. 1965. Botanical composition of sheep and cattle diets on a mature annual range. Hilgardia. 36:465-470.

Vavra, M., and J.L. Holechek. 1980. Factors influencing microhistological analysis of herbivore diets. J. Range Manage. 33:371-374.

\section{First Call for Papers}

June 15, 1982

Titles are now being solicited for papers to be presented at the 1983 Annual Meeting of the Society for Range Management in Albuquerque. Papers may be submitted in the following general categories:

1. Range animals-production; diets and nutrition; wildlife; insects; other animals.

2. Range plants - collection; selection and breeding; germination and establishment; physiology; morphology; taxonomy.

3. Soil and water-range watershed management, rangeland hydrology; grazing and water management; soil fertility and management.

4. Range ecology and range ecosystems-succession; fire; nutrient cycling; drought; community or ecosystem classification.

5. Range management systems-grazing systems; forest grazing, complementary forages; grazing impact.

6. Range inventory and evaluation-range inventory; survey methods.

7. Range improvement and land reclamation-renovation, seeding, brush and weed control, fertilization, reclamation and stabilization of disturbed lands.

8. Sociological and political concerns-history, education, communications, technology transfer, international programs.

9. Range economics and management-production costs and returns; modeling; computer utilization.

10. Ranching practices-ranching experiences, enterprise concerns; technology integration.

The title of the proposed paper accompanied with 1 or 2 sentences describing the emphasis of the paper and the 1st, 2nd and 3rd choices of preferred categories are due on June 15. Upon receipt of titles, authors of technical papers will be furnished instructions for preparing abstracts in a standard format. Completed abstracts are due on August 15. Authors will be notified of paper acceptance or rejection by mid-September.

Presentations must be planned to conform to a 12-minute presentation. Visuals must be standard $2 \times$ 2 slides. Attempts will be made to place titles in categories of the author's choice. A heavy volume of titles in any one category may result in placement in an alternate category. Titles and/or abstracts received after their due date will be accepted only as space allows.

Titles and abstracts should be sent to:

Gary B. Donart or Rex D. Pieper

Co-Chairman 1983 SRM Program Committee

Department of Animal and Range Sciences

New Mexico State University

Las Cruces, New Mexico 88003 